\title{
ВЫПРОСЬТ ЗА ЛИДЕРСТВОТО НА НАРОДНОЛИБЕРАЛНАТА ПАРТИЯ СЛЕД УБИЙСТВОТО НА СТЕФАН СТАМБОЛОВ
}

\section{Д. Костадинова}

Костадинова Д. Питання про лідерство в Народно-ліберальній партії після вбивства Стефана Стамболова. У статті аналізується ідейна еволюція видатного болгарського державного діяча Ст. Стамболова, зокрема причини його розриву з П. Каравеловим та обставини заснування Народно-ліберальної партії після державного перевороту 1886 р. Оцінюючи іiі як партію лідерського типу, автор дає оцінку ії очільникам, що визначали обличчя партії після смерті Ст. Стамболова.

Ключові слова: Болгарське князівство; партійно-політична система; Стефан Стамболов; Народно-ліберальна партія.

Костадинова Д. Вопрос о лидерстве в Народно-либеральной партии после убийства Стефана Стамболова. В статье анализируется идейная эволюция выдающегося болгарского государственного деятеля Ст. Стамболова, в частности причины его разрыва с П. Каравеловым и обстоятельства учреждения Народно-либеральной партии после государственного переворота 1886 г. Оценивая ее как партию лидерского типа, автор дает оценку ее руководителям, определявшим лицо партии после смерти Ст. Стамболова.

Ключевые слова: Болгарское княжество; партийно-политическая система; Стефан Стамболов; Народно-либеральная партия.

Kostadinova D. The issue of leadership in People's Liberal Party after the murder of Stefan Stambolov. The article analyzes evolution of ideas of outstanding Bulgarian statesman St. Stambolov, particularly the reasons of his rupture with P. Karavelov and the circumstances of foundation People's Liberal Party after coup d'etat in 1886. Treating the party as a leadership one, the author evaluates its leaders, who defined the face of the party after the death of Stambolov.

Keywords: The Principality of Bulgaria; party-political system; Stefan Stambolov; People's Liberal Party.

Въпросът за лидерството на Народнолибералната партия е изключително важен, тъй като както и другите политически партии, появили се в страната ни след Освобождението, така и тази партия е от лидерски тип. Терминът „лидерски тип“ обаче е съвременна модификация на битуващия през втората половина на XIX - първата половина на XX в. термин „шефски тип“. Значението и на двата е едно и също. Лидерьт или шефът е всичко за партията. Той е, така да се каже, белият дроб, чрез който тя диша и живее. При това лидерьт или шефът не е необходимо да заема някакъв пост в ръководните органи на партията. От него обаче зависи кой да бъде председател на централното ѝ бюро, кой да бъде главен редактор на партийния орган и пр. Припомняме всички тези добре познати факти, тъй като към тези правила се е придържал и самият Стефан Стамболов, когато пристъпя към изграждането на своята политическа формация, наречена Народнолиберална партия.

Малцина от неговите биографи са си задавали въпроса: защо той я наименува така. Според нас това не е случайно негово хрумване, а резултат от редица фактори и обстоятелства. Когато Народнолибералната партия се появява на политическата сцена в България, не само в Княжеството, но и в цяла Европа с особена популярност се ползват няколко идейни течения. Ако започнем да ги броим от дясно наляво, на първо място следва да се постави консервативното. Негови прояви са различните политически партии, които в различните страни носят различни имена, но идейната им същност е една и съща. У нас такава е старата Консервативна партия, която произлиза от консервативното течение, зародило се по време на Учредителното събрание, заседавало в Търново през 1879 г. Скоро след това то се обособява и в политическа партия под същото наименование ${ }^{1}$. При все че в редовете ѝ членуват заможни лица, Консервативната партия не успява да се разрасне като влиятелна политическа сила и след Съединението на Източна Румелия с Княжество България през 1885 г. просто изчезва от политическото пространство на Княжеството.

Другото идейно течение в Европа е либералното, чиито разновидности в различните страни са още по-многобройни от тези на консервативното. У нас обаче то се проявява под

(C) Костадинова, Д., 2015 
класическото название „либерално“. Както консервативното, така и то също се заражда по време на Учредителното събрание от 1879 г. Като партия и то се обособява след закриването на Учредителното събрание 2 .

Лидерите и на двете партии са лица добре известни, с богат политически опит, придобит още от предосвобожденската епоха. Главно поради възрастови причини Ст. Стамболов не влиза в тяхната среда. Политическите му пристрастия обаче са на страната на Либералната партия. Ако за някои други политически дейци от онова време принадлежността им към Либералната партия може да се сметне като позитивен акт, същото не може да се каже за младия търновец, тъй като влизането му в Либералната партия означава, че той вече е еволюирал от революционните си възгледи, които е имал в предшестващата възрожденска епоха. За него участието му в Либералната партия е еволюция надясно, което е по-рядко срещано явление сред политическите дейци, които в повечето случаи еволюират от дясно наляво. Примери за такъв процес има стотици в европейската и световната история, има такива и у нас. Нека само си припомним случаите с Кимон Георгиев, Дамян Велчев, които от върли монархисти стават републиканци и пр. ${ }^{3}$ Идейната еволюция на Ст. Стамболов е твърде съществен въпрос, но тук няма да се спираме по-подробно на него, тъй като това би ни отклонило от задачата, която сме си поставили.

Като член на старата Либералната партия, Ст. Стамболов е непосредствен свидетел на нейното изграждане като политическа формация от страна на Драган Цанков, Петко Каравелов и Петко Рачов Славейков. И към тримата партийни лидери той изпитва истинско уважение, учи се и от техния опит. Искреното му желание е Либералната партия да запази своята монолитност, тъй като след нея върви и по-голямата част от българската общественост по онова време. За голямо негово съжаление, това обаче не се получава. Подложена на различни атаки, най-вече от страна на княз Александър I Батенберг и консерваторите, тя започва да се раздира от вътрешни политически трусове, които излизат на повърхността на политическия живот в Княжеството през септември 1883 г., когато Др. Цанков, за да се сложи час по-скоро край на установения по онова време Режим на пълномощията, дава съгласието си пред княза за формиране на коалиционно правителство с консерваторите 4 За Петко Каравелов и Петко Рачов Славейков това е неприемлив ход и те се обявяват открито против него 5 . До пролетта на 1884 г. Либералната партия обаче съществува като единна формация. Разцеплението в редовете ѝ се извършва след парламентарните избори за IV Обикновено народно събрание от май 1884 г., когато Др. Цанков е дезавуиран от своите политически привърженици, поради което е принуден да подаде оставката си от министър-председателския пост. За нов министър-председател е назначен главният му политически опонент Петко Каравелов, който току-що е бил избран за председател на новото Народно събрание 6 .

Ще отворя една малка скоба: в избора за председателския пост на IV Обикновено народно събрание наред с П. Каравелов се кандидатира и Ст. Стамболов. Кураж за тази постъпка му дава фактът, че вече е бил подпредседател на II Обикновено народно събрание и че познава добре парламентарната практика. А дали това е било като акт на поставленик на Др. Цанков, както се споменава в някои публикации, или не, на този въпрос сега няма да се спираме. Ще отбележим само, че мнозинството от депутатите подкрепят кандидатурата на П. Каравелов, което е пряка последица от самия облик на партията - лидерския. По тази причина, макар и да е бил добре познат на българското общество, Ст. Стамболов търпи провал. След като П. Каравелов става министър-председател, на проведеното ново гласуване за председател на Народното събрание Ст. Стамболов отново се кандидатира и този пьт печели избора. Последвалият му успех нямаше да се получи, ако за него не бе дал съгласието си самият партиен лидер П. Каравелов ${ }^{7}$.

Изборът на Ст. Стамболов за председател на IV Обикновено народно събрание в края на юни 1884 г. слага край и на колебанията към кое от двете течения на Либералната партия да се присъедини. Макар че симпатиите му са били повече към стария Др. Цанков, преминава към крилото на П. Каравелов. И трябва да подчертаем, че до август 1886 г. Ст. Стамболов е верен поддръжник на своя партиен лидер. Разривът между двамата избухва след детронирането на княз Александър I Батенберг, което по същество е истински държавен преврат. По станалото събитие двамата дейци заемат различна позиция: П. Каравелов проявява колебание, от което не се освобождава. Ст. Стамболов, когото превратът 
заварва в родния му град Търново, отначало също се въздържа от каквато и да било проява. Полага неимоверни усилия да се осведоми за това как и от кого е извършен превратьт и особено от това как той се посреща в страната. Когато узнава, че срещу акцията се обявяват някои от големите гарнизони в страната, той решава да се присъедини към тях ${ }^{8}$.

От този момент насетне той не само се разделя с П. Каравелов, но счита последния и за свой главен политически противник, с когото по-късно ще се разправи по особено жесток начин. Така е: в политиката няма сантименти - има само борба и то борба за интереси, борба за политическо надмощие. След преврата от 9 август 1886 г. надмощие в политическия двубой с П. Каравелов взема Ст. Стамболов. Раздялата с П. Каравелов не е само личностна, но и политическа. Казано с други думи, Ст. Стамболов напуска и оглавяваното от него течение в старата Либерална партия, което на практика означава, че той трябва да изгради свой нов политически пристан.

Докато още е регент, Ст. Стамболов се опира на подкрепата на патриотическите дружинки „България за себе си“, състоящи се в мнозинството си от бивши поборници и опълченци . Когато обаче новоизбраният княз Фердинанд през август 1887 г. го поканва да заеме министьр-председателския пост, той разбира, че не може да се осланя повече на тези формации и че ще му трябва далеч по-сигурна политическа опора, на която да разчита формираният от него кабинет. Така се стига до идеята за създаването на Народнолибералната партия. От самото ѝ име проличава, че тя ще бъде поредната издънка от старата Либерална партия, към която обаче се полагат усилия да бъдат привлечени и лица, и групи от други политически среди, които споделят идеологията на министьр-председателя.

Модельт вече го има - това е старата Либерална партия. Остава да се пристъпи към неговото конкретно осъществяване. Зает премного с административни задължения като министър-председател и министьр на вътрешните работи, Ст. Стамболов възлага тази неимоверно трудна и отговорна задача на един от своите най-близки съратници - Димитър Петков ${ }^{10}$.

Въпреки появилите се в последните години публикации в историческата ни литератуpa, следва да се каже, че неговата личност продължава да бъде в забвение. А това е крайно незаслужено за него, тъй като той има зад себе си богата биография. Добруджанец (роден в с. Баш кьой, Тулчанско), закърмен с революционните възрожденски идеи, Д. Петков взема участие в Руско-турската освободителна война от 1877-1878 г. За проявения героизъм е награден лично от император Александър II. След Освобождението се отдава на журналистика и публицистика. Политическите му пристрастия са също към старата Либерална партия. От тримата ѝ лидери най-много му импонира личността на стария Петко Рачов Славейков и то не толкова като политическа фигура, колкото като журналист и публицист. От него той се учи, пристъпвайки към новото си поприще. Като деец на Либералната партия няма лидерски амбиции, каквито има Ст. Стамболов. И ако не бяха настъпили събитията от 9 август 1886 г., той навярно щеше да си остане на журналистическото и публицистично поприще. Развоят на последвалите след държавния преврат събития обаче го хвърля и в пламъците на ожесточена политическа борба. Преминал на страната на Ст. Стамболов, без да се отказва от журналистиката и публицистиката, поема задължението не само за изграждането на Народнолибералната партия, но в продължение на седем години е и столичен кмет. Известно време е и председател на IV Велико народно събрание, както и на VI и VII Обикновено народно събрание, закратко е и министър на обществените сгради, пътищата и съобщенията в последния кабинет на Ст. Стамболов преди падането му от власт през май 1894 г. ${ }^{11}$

Към своята партия Ст. Стамболов се връща едва след като минава в опозиция. Но и тогава не заема никакъв отговорен пост в нея. Председател на Централното бюро продължава да бъде Димитър Петков. Той обаче е лицето, което дава главните насоки на нейната дейност.

Минаването на Ст. Стамболов в опозиция му подейства шокиращо. Дори и в найкошмарните си сънища не е допускал какво ще му се случи с него. Непосредствената му близост с княз Фердинанд в продължение на седем години му позволява да разбере с какъв владетел си има работа. Няма да се впускаме в подробности, но не можем да отминем добре известния факт, че още при посрещането му във водите на р. Дунав край Видин през далечната 1887 г. личността на новоизбрания княз не му се понравя. Още 
тогава той споделя пред придружаващите го лица, че с този човек ще си има много неприятности. След като го опознава от по-отблизо, ще каже и добре известните думи, че българският народ ще му прости всички грехове, но не и този, дето е довел Кобурга в България. А на смъртния си одър, малко преди да издъхне, успява да промълви само на стоящата до него плачеща съпруга: да не стъпва никога в Двореца и от Двореца нищо да не взема ${ }^{12}$.

Въпреки прикритата или дори открита неприязън към личността на княза, като министър-председател Ст. Стамболов полага големи усилия да пренебрегне личните си чувства и прави всичко възможно за утвърждаването на неговия авторитет на държавен глава, както това изискват повелите на самата Търновска конституция. В някои отношения дори отива и по-далеч, като променя известния чл. 38 от Конституцията, отнасящ се до вероизповеданието на княза ${ }^{13}$. Казано накратко, Ст. Стамболов е искал да осигури всички условия на Кобурга да царува в България. Изобщо не си е и помислял, че последният има далеч по-големи амбиции - не само да царува, но и да управлява. Още по-малко е предполагал, че всеки, който се изпречи на пътя му за постигането на тази цел, ще бъде премахнат без оглед на мястото, което заема в политическия живот на страната.

Истинското лице на княз Фердинанд проличава след министерската промяна от май 1894 г. Едва тогава Ст. Стамболов разбира, че амбициите на княза няма да се ограничат само с политическото му отстраняване, но че ще отиде и по-нататък - с физическото му ликвидиране. Отказът на правителството на д-р Константин Стоилов да му издаде задграничен паспорт, за да отиде да се лекува в чужбина, вече го убеждава в това му предчувствие. Изпълнението на смъртната присъда над него е само въпрос на време. И това се случва, когато той най-малко очаква - в разгара на лятото на 1895 г.

Трябва да се признае, че последвалото му убийство нанася непоправим удар върху съдбата на Народнолибералната партия. Макар че просьществува самостоятелно чак до 1920 г., тя никога повече няма да достигне онзи ръст и влияние, които има по времето на управлението на Ст. Стамболов (1887-1894 г.). Дори и през периода 1903-1908 г., когато е отново начело на управлението на страната, тя вече е политическа формация от по-второстепенен ранг.

Заместници на Ст. Стамболов като лидери на Народнолибералната партия, освен Димитър Петков, стават Димитър Греков ${ }^{14}$ и д-р Никола Генадиев ${ }^{15}$, които също са ярки политически личности, с богата биография и жизнен опит. Пьрвият от тях е юрист по професия. Получава известност като един от лидерите на старата Консервативна партия. След като в средата на 80-те години на XIX в. тази партия престава да съществува, той се ориентира към партията на Ст. Стамболов. Вторият също е юрист по професия. Заедно с това, съвместно с по-големия си брат Харитон в началото на 90-те години на XIX в. пристьпва към издаването на ежедневника „Балканска зора““, който първоначално е с антистамболовистка насоченост. Скоро след това прави завой на 180 градуса и се преврьща в един от най-ярките поддръжници на първия стамболовистки режим. Амбициите му за лидерския пост в партията се пораждат след смъртта на Димитьр Петков и на Димитьр Греков (който, впрочем, умира преди убийството на Дим. Петков през 1907 г.). На тях обаче им липсва харизмата на Ст. Стамболов. Макар и преминал в небитието през 1895 г., Ст. Стамболов си остава неоспорваният авторитет в средите на членската ѝ маса до 1920 г., пък и след това, до окончателното ликвидиране па политическите партии от режима на звенарите след преврата от 19 май 1934 г.

След промените от 1989 г., когато у нас настьпи ерата на политическия плурализъм, бе направен опит за реанимиране и на Народнолибералната партия. Той се оказа неуспешен главно поради това, че отново липсваше личност от ранга на Ст. Стамболов.

\footnotetext{
${ }^{1}$ По-подробно вж. Гешева Й. Образование Консервативной партии в Княжестве Болгарии // Bulgarian historical review. - 1993. - № 2-3. - P. 180-192.

2 По-подробно вж. Стоянов Ив. Либералната партия в Княжество България (1879-1886). София, 1989.

${ }^{3}$ Недев Н. Три държавни преврата, или Кимон Георгиев и неговото време. - София, 2007.

${ }^{4}$ По-подробно вж. Димитров Ил. Режимът на пълномощията и борбата против него (1881-1883) // Годишник на Софийския университет. - Идеологически катедри. - 1965. - Т. 58. - С. 299-387.
} 
5 По-подробно вж. Косев Д. Петко Рачов Славейков. Обшествена и политическа дейност. -2. изд. - София, 1986; Кожухаров К. Петко Каравелов. Историческа хроника за него и неговото време. - София, 1968.

${ }^{6}$ По-подробно вж. Стоянов Ив. Либералната партия...

${ }^{7}$ Стенографски дневници на IV Обикновено народно събрание, 30.VI.1884.

${ }^{8}$ По-подробно вж. Попов Р. България на кръстопьт. Регентството 1886-1887. - София, 1991.

9 По-подробно вж. Попов Р. Към историята на дружината „България за себе си“ (1886-1887) // Исторически преглед. - 1991. - № 11. - С. 21-41.

${ }^{10}$ По-подробно вж. Топенчаров, В. Българската журналистика 1885-1903. - Кн. 1. - София, 1963. - С. 82 и сл.

${ }^{11}$ По-подробно вж. Попов Ж. Бурният живот на Димитьр Петков. - София,1998.

12 По-подробно вж. Иванов Д. Стефан Стамболов - от перото до ятагана. - София, 2005.

${ }^{13}$ По-подробно вж. Петков П. Ст. Православная церковь и государственная власть в Княжестве Болгарии // Bulgarian historical review. - 2000. - № 3-4. - Р. 54-75.

${ }_{14}$ Кънчов В. Д-р Димитър Греков // Летопис на Българското книжовно дружество. - 1902. C. $72-80$.

${ }^{15}$ Грънчаров Ст. Д-р Никола Генадиев и неговите спомени // Генадиев Н. Мемоари. - София, 1985. - C. 5-16. 